\title{
The Dating and Interpretation of a Field Wall in Öggestorp
}

Leif Häggström, Joanna Baran, Alf Ericsson \& Andrew Murray

\begin{abstract}
The interpretation of the use and contextual meaning of fossil agrarian forms is connected with their age. In this article we discuss the dating and interpretation of a field wall in Öggestorp, situated on the northern rim of the southern Swedish uplands in the province of Småland. Öggestorp is a complex archaeological site dating from the early Iron Age $(500 \mathrm{BC}$ to $\mathrm{AD}$ 550). The site was also used for various forms of agriculture during the Middle Ages and in early modern times, a fact which complicates the dating and the interpretation of the agrarian features. We discuss the possibility and practical issue of dating agrarian sediments by optically stimulated luminescence (OSL). By combining OSL and other methods, a reliable estimation of age can be established. The paper also deals with the possible implications of the OSL-method in relation to the current state of knowledge of agrarian structures. We show that a serious dating of agricultural remains must be based upon a critically used combination of methods. Without a well-argued date, it is difficult to relate any agrarian form chronologically to other remains in a fossil landscape of multilayered complexity.
\end{abstract}

Leif Häggström, (Corresponding author), Jönköpings läns museum, Box 2133, SE 55002 Jönköping, Sweden.

Joanna Baran, Department of Radioisotopes, Institute of Physics, Silesian University of Technology, PO 44-100 Gliwice, Poland.

Alf Ericsson, Riksantikvarieämbetet (National Heritage Board), UV Öst, Roxengatan 7, SE 58273 Linköping, Sweden.

Andrew Murray, Nordic Laboratory for Luminescence Dating, Department of Earth Sciences, University of Aarhus, Risø National Laboratory, DK 4000 Roskilde, Denmark.

Key words: Early Iron Age, field wall, Optically Stimulated Luminescence (OSL), southern Swedish uplands, agrarian structures

In 2002 a major archaeological excavation was carried out in Öggestorp, not far from Jönköping in southern central Sweden (the province of Småland). Öggestorp is one of the most complex archaeological sites in the southern Swedish uplands. Substantial remains from the early Iron Age (500 BC to AD 550) are still visible in the landscape. If complemented with other sources, Öggestorp has much to offer those interested in the long-term development of the agrarian landscape. 


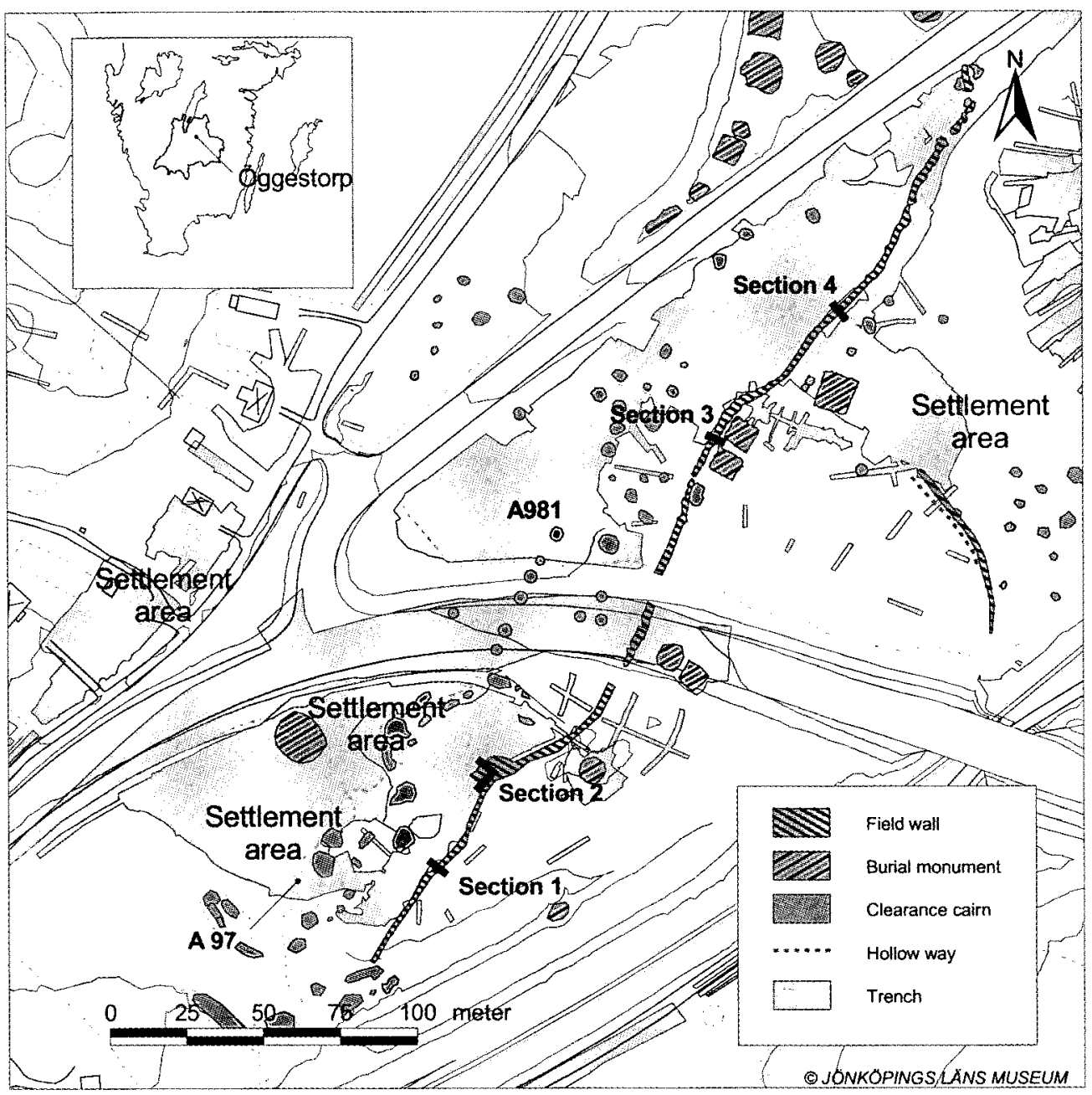

Fig. 1. Map showing the location of Öggestorp as well as important features and a projection of different generations of trenches dug in different archaeological excavations at Öggestorp. Existing roads, a railroad and demolished houses are also shown. Map by Samuel Björklund, of the Jönköping County Museum.

The excavation covered an area of approximately 40,000 square metres. The excavation in 2002 was, however, not the first in Öggestorp. Including earlier investigations, some 75,000 square metres have been excavated in a restricted area (Fig. 1). Different kinds of archaeological remains have been excavated. Settlements from the early Iron Age with house constructions have been identified in three different places, probably representing different farmsteads. Two of these were excavated in 2002 and are of primary interest in this paper. The third settlement is situated some 500 metres south-west of the other two. Traces of cultivation, consisting mostly of clearance cairns and field walls, were in many cases of uncertain age and function before the investigation. Graves, primarily from the early Iron Age, have also been excavated. The settlements and graves can almost 
always be dated by artefacts and radiocarbon-dated charcoal. The radiocarbon dates all indicate that the majority of the settlement remains and graves are from the early Iron Age. Most of the radiocarbon dates of the agricultural remains tell a different story. All but one of these dates are from early modern times (after $\mathrm{AD}$ 1500), despite the fact that the physical remains of agricultural activities have close geographical connections with the settlements and graves. The main task to be done in order to be able to interpret the area is to settle the age of the agrarian forms.

This article will focus upon the dating of one of the main features in the area - a field wall (Sw. stensträng). The field wall in question was most probably a boundary ( $\mathrm{Sw}$. begränsning) between an infield with arable land (Sw. inägomark) and outlying lands with pastures (Sw. utmark). The terrain and several archaeological observations certainly suggest this. But if the field wall fulfilled a function as a barrier/enclosure ( $\mathrm{Sw}$. hägnad), i.e. a serious obstacle to grazing animals, it must have carried a wooden superstructure, probably some kind of fence. If the field wall functioned as a barrier between arable land and pasture, it is of great importance to date it correctly, as the result can have a bearing on the dating of the introduction of the permanent separation between infields and outlying lands in the southern Swedish uplands, especially in northern Småland. Different methods of dating the field wall will be discussed and a cultural-historical interpretation will be presented.

The Öggestorp site is extensive. This study primarily concerns the major field wall and will concentrate on that feature (Fig. 2). Other features nearby or of other relevance to the study will be discussed only briefly.

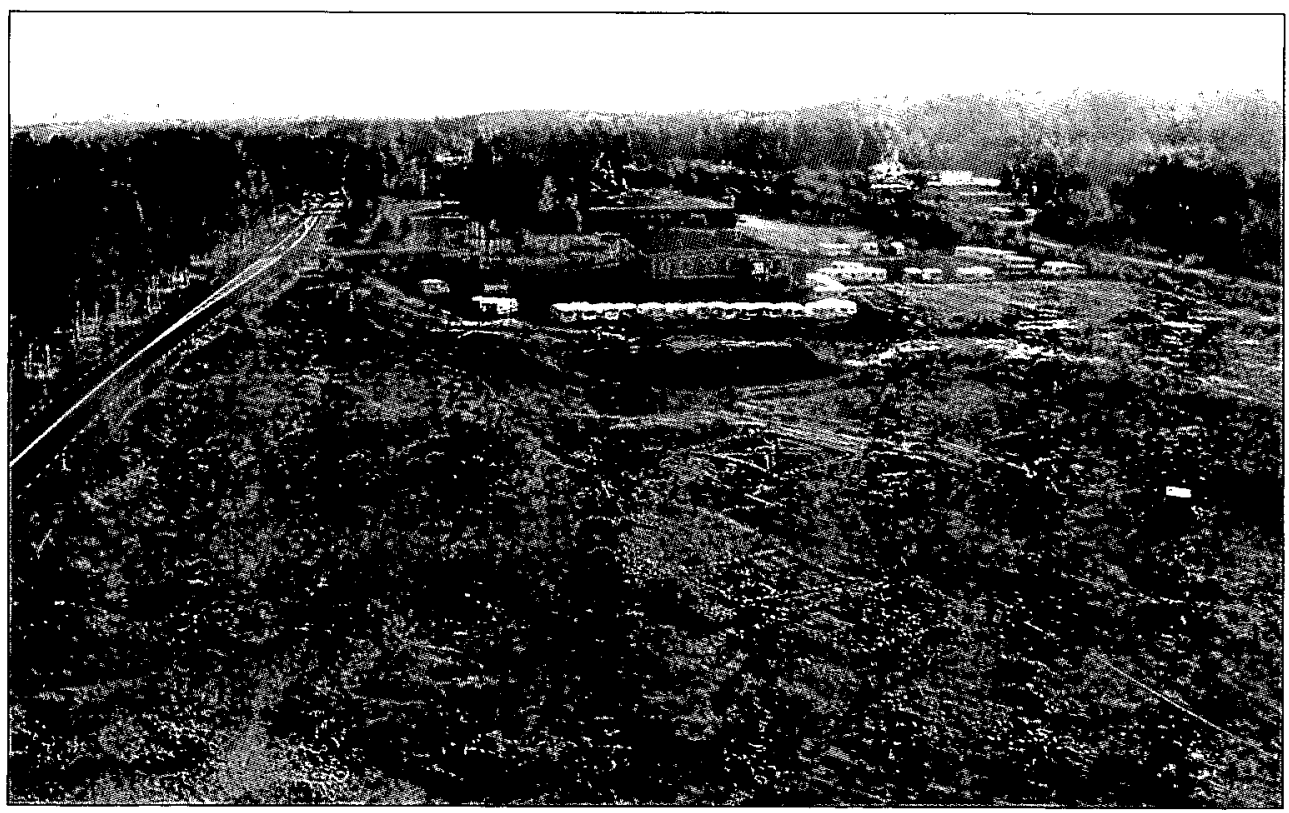

Fig. 2. An overview of the northern part of the site. Photograph by Jönköping County Museum 


\section{INTRA-SITE RELATIONS}

The long and winding wall dominates the site and can be traced for some 500 metres. Its southern part ends at a railway built in the $19^{\text {th }}$-century. No traces of the field wall can be found south of the railway where arable fields dominate the landscape. If the field wall continued here, it was long ago destroyed by agriculture. Early $20^{\text {th }}$-century buildings have damaged the northern part of the wall. The buildings are a part of the modern Öggestorp village and are primarily situated on the infields of the old rural hamlet. A road constructed in 1936 crosses the wall at one point and a major road constructed in 1989 crosses it at a different one. The field wall is fragmented but must none the less be considered a relic of an important element that once structured the landscape in a most significant way.

The land on both sides of the field wall has been used in various ways. The southern part of the wall separates an area of land useless for cultivation, with lots of stones and boulders, probably used as pasture, from an area of settlements, arable fields and traces of ironwork. There is no doubt that the outlying lands were situated on the former (eastern) side and the infields with adjoining settlements on the opposite (western) side.

The middle part of the wall winds its way around two quadratic grave monuments. The building of the field wall seems to have respected these monuments. Grave monuments of this type are usually dated to the early Iron Age (Engman \& Nordström 2001). A quadratic grave monument with finds of weapons from the early Roman Iron Age (B1) was excavated in the 1950s. The artefacts consisted of a fragment of a shield, a sickle, a fibula and cremated bones (Engman \& Nordström 2001; Nicklasson 1997:75). Close to the two "respected" quadratic grave monuments, a gate was identified in the field wall (Fig. 3). The gate was planned when the field wall was built. It is slightly less than 1 metre wide and is marked by two flanking boulders. This can be interpreted as meaning that the

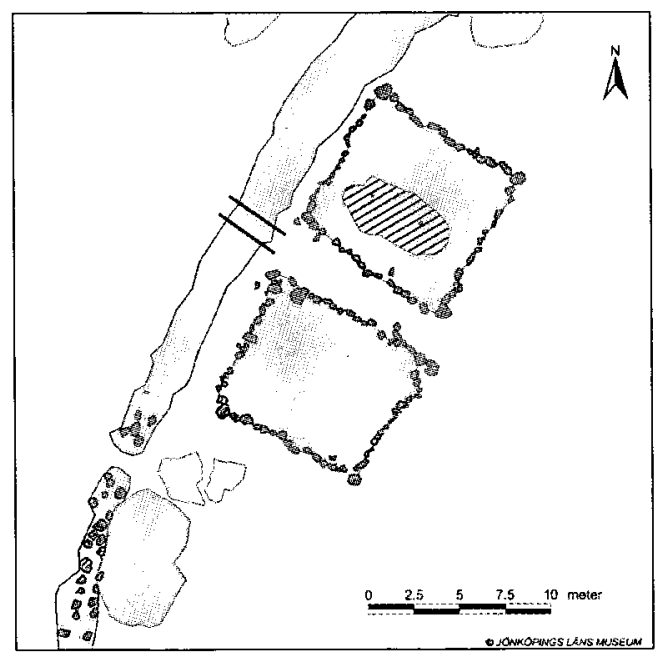

monuments were in some kind of use, and an opening from the area west of the field wall to the monuments was needed. This implies that the field wall was erected after the monuments, but at a time when the monuments were still active parts of the cosmology of the residents using the land, building the wall and planning the landscape.

Fig. 3. Map showing the relation between two quadratic grave monuments and the gate in the field wall. The marked area in the northern monuments is an area that was looted long before the excavation was carried out. Map by Samuel Björklund, of the Jönköping County Museum. 


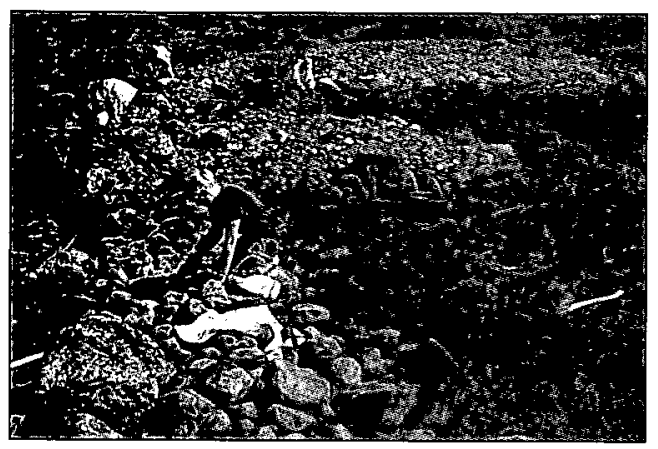

Fig. 4. Excavating the field wall. Photograph by Jönköping County Museum.

If the monuments were no longer in ritual use at the time of the building of the field wall, it would have crossed the monuments, instead of respecting them and winding its way around them. If the field wall was built prior to the monuments, it would also have gone in a straight line, instead of winding round the non-existent monuments (Fig. 4).

An argument for the introduction of infields in the Roman Iron Age can be found in the palaeobotanical data from the site. Seeds of gold-of-pleasure (Camelina sativa, Sw. oljedådra) were found at one of the settlements. Gold-of-pleasure is an oilseed used for the extraction of oil. It is fairly uncommon in prehistoric settlement contexts, probably because it is easily destroyed. Gold-of-pleasure demands the well-maintained and fertilized fields maintained by the infield system (Regnell 2003).

The intra-site relations of the field wall thus imply that it was planned and partially built as a boundary between infields and outlying lands. They also imply that it was probably constructed in the later part of the early Iron Age, depending upon the age of the two quadratic grave monuments. Unfortunately no artefacts or constructions were identified when the monuments were excavated, which means that they have to be fixed in time by analogy with similar monuments with artefacts of known age. It is, however, an entirely different question whether it is right to label monuments as "graves" when no traces of cremated or decomposed bodies were found.

\section{LAND-SURVEY MAPS AND MEDIEVAL RECORDS}

By studying land-survey maps from the $17^{\text {th }}$ and $18^{\text {th }}$-centuries and historical records from the Middle Ages (AD 1050-1500), the historical use and organisation of the area can be established. The Iron Age site, consisting of at least two farmsteads, is located on the land of two historically different hamlets: Rommelsjö is situated in the southern part and Öggestorp in the northern. The Rommelsjö part has been used for cultivation at least since the $17^{\text {th }}$-century while most of the Öggestorp part has been used for grazing in historical times. However, the grazing has been improved by occasional, fire-based clearing of the fields, something which is mentioned by the landsurveyor in a map from 1701 (Sw. uttaget till fälle) (Vestbö-Franzén 2002:104). The use of fire in the landuse in historical times suggests that charcoal found in the topsoil or in stone structures not can be trusted to represent the primary use or establishment of the area and objects. Charcoal found in such contexts is more likely to have originated from the fire- 
based activities of historical times than from prehistoric activities, such as clearing the land in preparation for cultivation. Charcoal found in the lower part of an agrarian feature may have originated from activities prior to the building of the structure.

The field wall winds its way over the site, crossing the property boundary between Rommelsjö and Öggestorp. The map of Öggestorp from 1701 shows an open-field system with three-course rotation (Sw. tresäde) (Vestbö-Franzén 2002:101-108). The map also shows the subdivisions (Sw. tegskifte), which are laid out in a regular fashion with permanent succession (Sw. solskifte) and proportionality in width to the size of the property. It is interesting to note that the

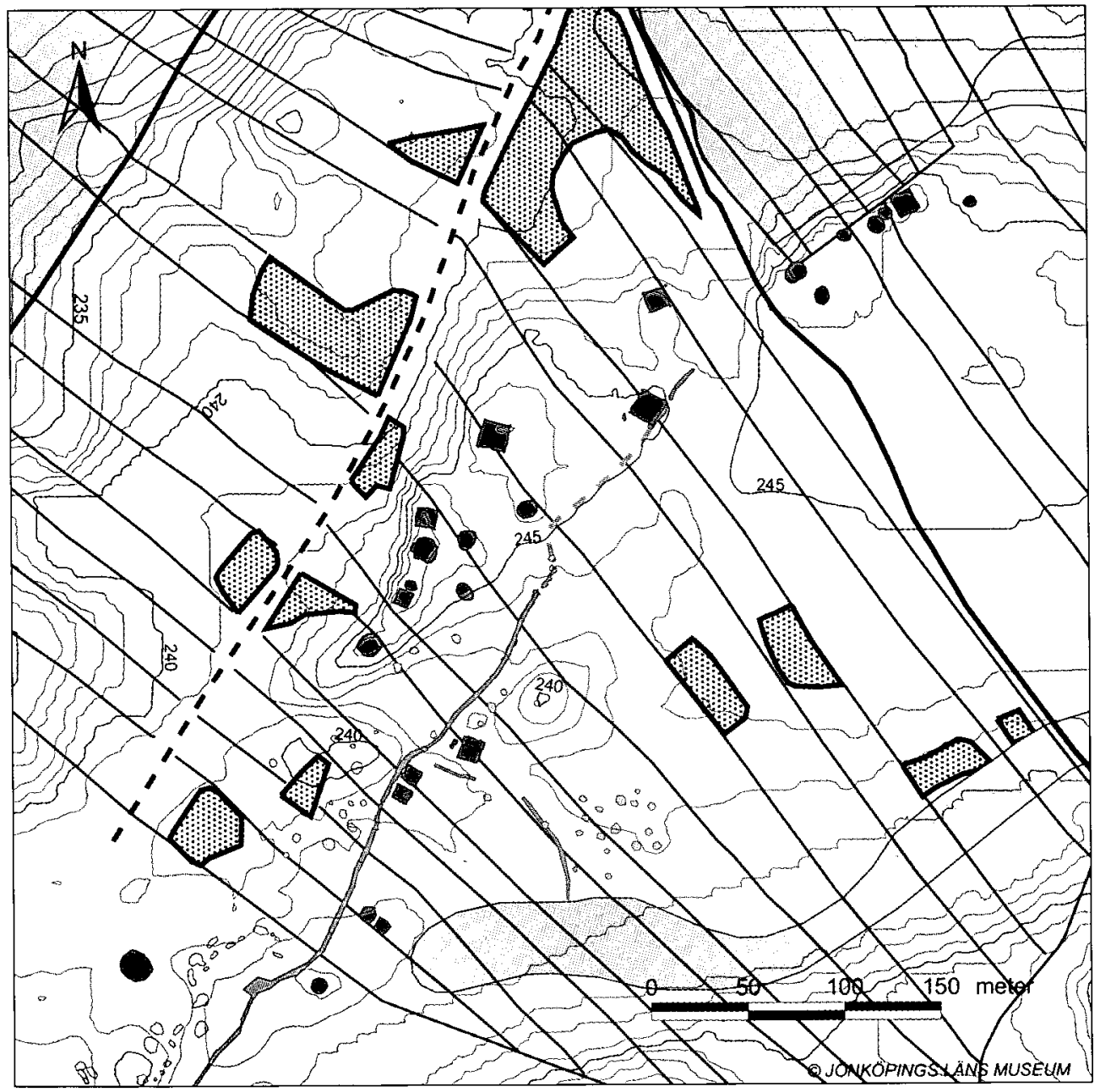

Fig. 5. Map showing grave monuments, clearance cairns and field walls. The extension of the major field wall has been partially reconstructed. The majority of the presented features must have existed in the late Roman Iron Age or at the latest in the Migration period. A rectified version of the 1701 map is projected on top of the prehistoric remains. Map by Samuel Björklund, of the Jönköping County Museum. 
subdivided fields show no respect for the three-field system, probably introduced in the $16^{\text {th }}$-century (Fig. 5). The subdivisions must therefore be older. Most of the arable land was concentrated in the vicinity of the settlement. The meadows were situated in the western part, close to a lake. There was also a lot of pasture in the infields, which were also subdivided according to the same system. This is, for example, the case where the field wall is situated. The fact that the field wall crosses the subdivisions in a discordant way shows that the former must be older than the latter. To sum up, there are no spatial relations between the field wall and the historical boundaries or land divisions. They represent two different structures in the landscape. The question is when the field wall was abandoned and the historical boundaries and landdivisions were established.

Rommelsjö first appears in written records in 1353 (DS 4947) and Öggestorp in 1268 (DS 537). But Rommelsjö and Öggestorp must have existed before the High Middle Ages. A terminus ante quem dating is given by the Romanesque church in Öggestorp, built in the $12^{\text {th }}$-century, and a large coin hoard from the end of the same century, found in the choir (Golabiewski Lannby 2002). In cadastral records from 1542 three farms (Sw. hemman) are mentioned in Öggestorp and five in Rommelsjö (Vestbö-Franzén 2002:110,113). According to a rule of thumb proposed by Lars-Olof Larsson (1981:473) a settlement unit with at least five farmsteads in $16^{\text {th }}$-century existed already in the year 1000 . According to the document from 1268 (DS 537) land in Öggestorp was assessed in the attung unit, a mansus concept. Assessment in this unit was probably established in the early 12 $2^{\text {th }}$-century (Dovring 1947:180; Ericsson 2000:30; Göransson 1985:70). At least this was the case in the plains of Östergötland, Närke and Öland. In the uplands of northern Småland, it was probably introduced a little later. A real assessment of land, as argued by Sölve Göransson (1985:66), is a prerequisite for the regular, eastern Swedish, subdivision system, founded on share-holding, as it was. For instance, in Västergötland, no real assessment of land was carried out and there the common fields were not subdivided according to the sophisticated system typical of eastern Sweden. The strip fields in Öggestorp were thus probably not laid out later than the $13^{\text {th }}$-century. There are no late Iron Age cemetreies in Öggestorp or Rommelsjö and both settlements must therefore be of late Viking Age or early medieval origin (i.e. $11^{\text {th }}-12^{\text {th }}$-century). Probably Rommelsjö, which is the larger settlement, existed before Öggestorp. The element -torp in placenames means approximately "new settlement". Thus, the field wall must be older than the late Viking Age or early Middle Ages.

\section{TYPOLOGICAL DATING}

Typological dating of agrarian structures is notoriously difficult. It may sometimes be possible regionally, but hardly for extensive territories (e.g. nations). The reason is, of course, that different geological conditions play a important role, as well as local tradition. Another problem in pinpointing general dates concerning agrarian features is that they are often the result of a long process, in which each year of 
use contributes to the final characteristic of the feature. Each feature must therefore be viewed as the sum of what has happened at the specific site. Nevertheless, some dates are generally accepted for specific features in specific regions.

A field wall (Sw. stensträng) is a linear element made of stones and sometimes soil in a fossil agrarian landscape. The field walls in Östergötland, southern Uppland, Västmanland and the islands of Öland and Gotland are organised in often large enclosure systems. However, the field walls in other provinces, for instance, Småland and Närke (Ericsson 1999) appear solitary, although associated with other agrarian features such as clearance cairns or terraces. Whether sites with solitary field walls, such as those at Öggestorp, have any chronological, functional or constructional similarity to the intricate enclosure systems found elsewhere is a question which demands further discussion.

A comparison between the field walls in Öggestorp and the field walls in the enclosure systems of Östergötland is tempting, because Östergötland and northern Småland are geographically close and have strong historical connections. The enclosure systems in Östergötland have attracted much attention during the $20^{\text {th }}$ century, and two main questions have been probed, concerning both date and function. In the 1920s and 1930s, it was suggested that the field walls were remains of defences connected with prehistoric battles and wars fought in the region (Edlund 1926). Arthur Nordén opposed this and suggested that the field walls were to be connected with prehistoric cult; this conclusion was based upon the relation between the field walls and prehistoric grave monuments (Nordén 1930, 1943). In the post-processual archaeology of the $1980 \mathrm{~s}$ and $90 \mathrm{~s}$, this relation came into focus afresh (Cassel 1998). However, since the 1950s, agrarian explanations have dominated. In 1953, Folke Dovring suggested that the field walls were to be interpreted as stone barriers built to manage cattle-breeding (Dovring 1953:49). Three major works raised a small debate when presented in the late 1960s and the early 1980s. They were Sven-Olof Lindquist's (1968), and Mats Widgren's (1983) dissertations, together with a work of settlement archaeology carried out by Evert Baudou (1973). Lindquist and Baudou were co-workers in the same project, concentrated on the Halleby site in eastern Östergötland. Lindquist argued that two kinds of field walls could be distinguished without archaeological excavation. One type functioned as barriers (Sw. hägnad) between infields and outlying lands. Other field walls were boundaries (Sw. begränsningar) of different kinds within the arable land. Lindquist also argued that the field walls are from the Iron Age. Baudou, on the other hand, argued that the enclosures are medieval. Widgren took up the thread and carried out new investigations. He concluded that the enclosure systems were from the Roman Iron Age or the Migration period. He was, however, sceptical as to whether the function could be discerned from the shape alone. He argued that any analysis must be based upon the construction of the wall but also upon its relation to other elements in the fossil landscape.

Nobody, however, tried to excavate a field wall of the barrier type to find out 
by way of reconstruction how it was originally constructed before Gert Franzén did so in 1994 (Franzén 1994). He concluded that the stones in the field walls were sufficient to reconstruct standing and firm walls made up of single walling (Sw. enkelmur). During the archaeological excavations in the extensive enclosure system near Väderstad in western Östergötland, three stone walls were reconstructed in their original positions (Ericsson 2001a:87-89). Two of them have been re-erected in the park belonging to the local historical society (Sw. hembygdsgård) in Väderstad. The reconstructed walls are of the single type and are $0.8-$ 0.9 metre high. The bases of two of them consist of erected boulders, on top of which rows of smaller stones are piled ( $\mathrm{Sw}$. ställd enkelmur). The other wall is of simple construction with just small, piled stones (Sw. staplad enkelmur). The latter type of wall has been in use in western Sweden up to modern times. Both types were high and firm enough to be barriers, keeping grazing animals away from the infields.

The conclusion that the field walls (of the barrier type) in Östergötland, and probably also in Uppland, Västmanland, Öland and Gotland, are collapsed standing walls has a bearing on previous radiocarbon dating. It is extremely important to know how the stone wall collapsed when the samples are collected. If charcoal is not sampled under the base of the once standing wall the dates will certainly be too late. At the best, something contemporary with the wall is dated.

Despite the geographical closeness between Östergötland and northern Småland, no enclosure system with field walls of the type known from Östergötland has so far been distinguished in northern Småland. In south-eastern Småland, near Kalmar, there are some small enclosure systems, which can be explained by the closeness to Öland, where the field walls are similar to those in Östergötland. The investigation of the major field wall in Öggestorp showed that it had never been a standing wall. There are thus no similarities with the field walls of Östergötland. The major field wall in Öggestorp consists of two parallel rows of boulders with a filling of smaller stones and soil. The width varies between 1.6 and 2.0 metres and the height is never more than 0.4 metre. The boulders were $0.25-0.4$ metres wide and the cleared stones usually not larger than 0.15 metre (Fig. 6). Also the construction indicates that the building of the field wall was planned.

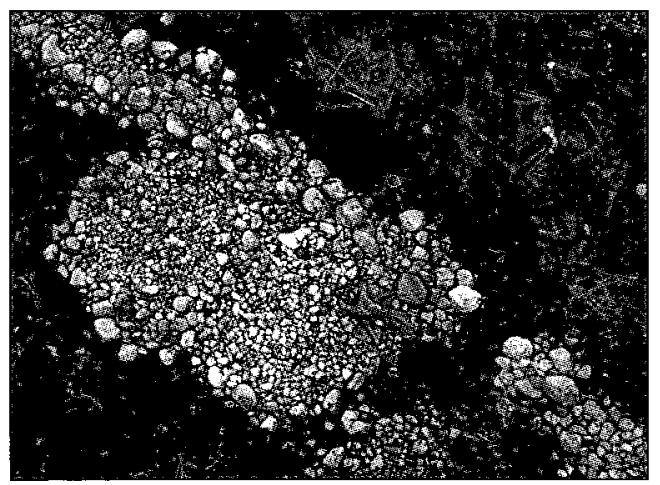
First, the double row of boulders was laid out on the ground, and then the cleared stones from the arable fields were thrown in the shell-formed construction. This kind of construction is in fact used to lodge stones cleared from arable fields. As stone-clearing

Fig. 6. Photograph showing the field wall and the gate. The construction of the field wall can be noticed. Photograph by Jönköping County Museum. 
is an annual activity, the filling in the field wall increased as long as the fields were cultivated. In the northern part, close to an arable field with no clearance cairns, the double walling with infill was totally covered with stones. However, if the field wall was to act as a barrier, preventing grazing animals from reaching the infields, it must have been supplemented by a wooden superstructure. The context of the field wall strongly suggests that this was the case.

The major field wall in Öggestorp can be said to be representative of the uplands in Småland and southern Västergötland, as it is part of a complex agricultural situation dominated by clearance cairns. In most cases, this kind of wall is, as in Öggestorp, constructed as a double walling with infill and has served as a field boundary with a probable barrier function ( $\mathrm{Sw}$. hägnadsvall). Some walls have been excavated and dated by radiocarbon analysis. The charcoal was usually collected under the wall and thus gives a terminus post quem dating of the construction. In Axlarp, south of Öggestorp, two field walls have been dated to the early Iron Age and early modern times. One wall in Flishult, further south, was dated $\left({ }^{14} \mathrm{C}\right)$ to the Roman Iron Age (Vestbö-Franzén 1997:201-206). As part of an extensive project concerning the earlier history of cultivation in the southern Swedish uplands (Det sydsvenska höglandets äldre agrarhistoria) a field wall in Norra Sandsjö was dated to the late Middle Ages/early modern times (Gren in press). In Rösered in Västergötland a field wall very similar to that in Öggestorp has been dated by pollen analysis (an insecure method) to the early Iron Age (Mascher 1993:59-67). In Månstad, also in Västergötland, another major field wall has been dated as early as the Pre-Roman Iron Age (Widgren 1990:14). Also in Närke, field walls of the Öggestorp type have been excavated and dated to the late Iron Age or the early Middle Ages. They functioned as barriers (probably with wooden superstructures) around subdivided open fields (Ericsson 1999).

Typological dating takes us nowhere closer to a plausible dating of the field wall in Öggestorp. It suggests that field walls of the Öggestorp type (double walling with infill) may date from the early Iron Age, just as well as from early modern times.

\section{STRATIFYING THE FIELD WALL}

The field wall rests upon a soil of unstable brown earth. In this region, this is often taken as an implication that the land was either cultivated in some way or used for grazing before the field wall was built. In one section the field wall lies superimposed on two hearths. Charcoal from both hearths has been ${ }^{14} \mathrm{C}$ dated to the Roman Iron Age (Ua-20817, $1870 \pm 45$; Ua-20818, $1775 \pm 40)$. The radiocarbon dates were determined on charcoal from hazel and willow, two trees with a short life span and typical of open grazing lands.

A huge number of clearance stones totally covered the double walling with infill in the northern part of the major field wall. These stones are a result of intensive clearing of the arable field to the west of the wall. The majority of the cleared stones now rest on the western side of the wall. It is interesting to note that 
no clearance cairns were found on this side of the field wall. Perhaps the arable field was rid of old clearance cairns when the field wall was built. However, it is difficult to decide whether the large number of cleared stones in this stretch of the field wall is a result of the intensity of the agricultural activity or its duration in time. Underneath some cleared stones outside the double walling, a post-hole was found. However, no radiocarbon analysis of material from the post-hole is available at the moment. Further to the north, a second opening, or gate, was identified in the wall. The gate is interpreted as secondary, as it is not flanked by boulders and because of the heaps of stones at the sides of the gate. It probably satisfied a later need to break through the wall in this area.

Stratigraphic relationships show that the field wall cannot have been built before the later part of the Roman Iron Age or the early Migration period. There are no clear indications of a secondary use of the field wall. When the opening in the northern part was made the field wall was perhaps abandoned and became just an obstacle to transports.

\section{RADIOCARBON DATING}

During the excavation in 1989 , one charcoal sample from the field wall was analysed. The result was a surprise; the wood was cut in the $15^{\text {th }}$-century AD (Beta 36848 , BP $455 \pm 55$ ). Charcoal from one clearance cairn and two quadratic grave monuments also turned out to be from historical times (Beta 36846, BP $720 \pm 80$; Beta 36863, BP $350 \pm 60$; Beta 36864, BP $280 \pm 90$ ). The dates from the quadratic grave monuments are anomalously young, compared with archaeological finds in other excavations in similar monuments in northern Småland (Engman \& Nordström 2001; Jansson 2002).

Charcoal in what was considered a good context was found in one of the clearance cairns during the excavation in 2002. The charcoal originated from alder and was dated to the Roman Iron Age (Ua-20815, BP $1885 \pm 45$ ). It is tempting to accept this date, as the charcoal sample was taken close to the bottom of the clearance cairn and may represent a fire-based clearing made in preparation for cultivation. It may on the other hand, represent older settlement activities with no connection with the agricultural activities that the cairn represented.

The main task here is to determine the relation between the dated organic material and the structure. At the Öggestorp site, there is only one convincing radiocarbon analysis of contextually acceptable charcoal from agricultural remains (a clearance cairn). It is, however, not plausible that all the clearance cairns are prehistoric. Many cairns in northern Småland have been dated to the Middle Ages or even early modern times (Vestbö-Franzén 1997).

\section{VEGETATION HISTORY}

Two different cores for pollen analysis have been taken not far from the Öggestorp site. The first pollen diagram was established in the 1990s and the second was sampled in 2001 and analysed in 2003. The first core was taken in a small lake 
called Femtingagölen, which lies a little more than $1 \mathrm{~km}$ west-south-west of the Öggestorp site. It has one major flaw, a hiatus between AD 800 and 1400. Per Lagerås has interpreted the diagram and drawn the conclusion that the first indications of woodland grazing appear between 1700 and $1500 \mathrm{BC}$. Later, grazing intensifies and the first indications of land clearing appear in $500 \mathrm{BC}$. In $\mathrm{AD} 250$, the first cereal pollen is identified (wheat and barley). The period AD 400 to 600 is expansive, followed by regression in $\mathrm{AD} 600$ to 700 . An agrarian expansion must have occurred sometime in the gap between AD 800 and 1400, as the postmedieval situation mirrors a more widespread agricultural activity than before (Lagerås 1996; 2002:46-53).

The second pollen diagram used samples from a peat bog some 400 metres closer to the Öggestorp site than Femtingagölen but in the same direction. The diagram covers the time span $1000 \mathrm{BC}$ to the present. In Leif Björkman's interpretation, the first indications of human impact appear in the period 600 to $475 \mathrm{BC}$ and represent extensive woodland grazing. In the period $475 \mathrm{BC}$ to $\mathrm{AD}$ 1, grazing starts to make a negative impact on some trees (ash, elm, lime and hazel) which can be seen to decline. The grazing is constant from AD 1 to 350 when it expands. Between AD 500 and 800, the grazing expands further and the first cereal pollen appears. From AD 800 to 1100 , a severe regression can be noted. The indications of grazing are heavily reduced and spruce forests are established. From AD 1250 to 1350 , a large expansion of grazing and cultivated land can be detected. Pollen from rye and wheat appears frequently. Grazing and cultivation seem to remain constant until AD 1700, from when a slight regression can be noted (Björkman 2003a:3-10).

The frequency of terrestrial pollen was analysed in different features at the Öggestorp site. Twenty-eight samples were analysed but only a few will be discussed in this context. The main problem with soil-bound pollen is preservation (Ranheden 1999). Soil is sometimes an extremely bad medium for the preservation of pollen; often only the most resistant pollen is preserved. Only the most characteristic pollens can be identified if they are badly preserved. Some species will therefore be over-represented and some not be represented at all. The potential of the method is that under good circumstances a local vegetation history can be identified. In the soil underneath a grave (A1), dated to the period $40 \mathrm{BC}$ to $\mathrm{AD}$ 30 (Ua-20807, BP $1980 \pm 45$; Ua-20808, BP $2030 \pm 35$ ), the preserved pollen shows an open landscape with pastures, fields and groups of birches. Close to a hearth (A97) that was dated to the period $180 \mathrm{BC}$ to AD 140 (Ua-19111, BP $2000 \pm 65$ ) five further samples were taken. Two were taken in the same layer as the hearth. These samples are badly preserved and indicate only the presence of pastures and a sparse birch forest (Björkman 2003b:6, 21, Häggström 2003).

\section{OPTICALLY STIMULATED LUMINESCENCE}

At present the only way of getting a direct date for an agricultural structure is to use the OSL method of dating sediments (Baran et al. 2003:1268-1270). As the 
method and its potential in archaeological contexts are little known among archaeologists in general, it deserves a short introduction (more extensive introductions to the technique and its applications can be found in Bøtter-Jensen 2000, Grün 2001, and Murray \& Olley 1999, among others).

Luminescence dating has been applied to sediments since the late 1970s. It makes use of the fact that daylight releases a charge from light-sensitive traps in the crystal matrix of quartz (or feldspar). These traps can store and accumulate a charge from background radiation over long periods. For this storage to begin, the mineral has to be concealed from daylight, e.g. by burial. When stimulated, the charge is released and some of it is given up as heat, some as visible light (often in the blue to the UV end of the spectrum); this is luminescence. If the charge is released by light, it is called optically stimulated luminescence (OSL) and if it is released by heat, it is called thermoluminescence (TL). The strength of the luminescence signal is related to the stored charge, which is in turn a measure of the dose (energy $/ \mathrm{kg}$ ) absorbed by the sample. The burial time is then equal to the dose divided by the background-radiation dose rate. The event dated is the last exposure to daylight (Murray \& Olley 1999:121-123).

The problem in dating the deposition of soil-derived sediments (such as those found within the field wall) is whether the individual grains were all exposed to sufficient daylight to be completely emptied of any prior luminescence signal. In such circumstances, the most information is obtained by using subsamples (aliquots) of only a few grains or even single grains. The single-grain method gives the opportunity to distinguish zeroed grains from poorly zeroed (partially bleached) grains, for which the small-aliquot method would give an overestimate of the age (Baran et al. 2003).

The samples in Öggestorp were taken from cavities from four different sections of the field wall and from one clearance cairn. The samples were analysed by both the small-aliquot and the single-grain methods. Both methods show a bleaching event some 6-8000 years ago. The single-grain method gave the most reliable result and is thus preferred in this context (Baran 2002, Baran et al. 2003).

The four samples from the field wall gave slightly different results. The sample from section 1 appeared to reflect a deposition event at about $500 \mathrm{BC}$ to $\mathrm{AD} 100$ and a further part of the sample reflected a medieval event. The sample from section 2 gave a date in the range $800-520$ BC. Sample 3 was dated to $1100-$ 500 BC. Sample 4 had similar features to sample 1 and reflected depositions at $100 \mathrm{BC}$ to $\mathrm{AD} 100$ with a further part giving a medieval age.

In order to check the reliability of the OSL dates of soil in Öggestorp two samples were taken from above and below a radiocarbon-dated hearth (A97). The results are presented in Fig. 7. Though slightly older, it is obvious that the OSL dates correspond well to the radiocarbon date (Baran et al. 2003:1269, Häggström 2003:43-44). 


\begin{tabular}{ll}
\hline Level & Date \\
\hline Above hearth (A97) & OSL-010414: 420-160 BC (soil) \\
In hearth (A97) & Ua-19111: 180 BC - 140 AD (2 sigma, 2000 $\pm 65 \mathrm{BP})$ \\
& OSL-010413: 600-200 BC (firecracked stone) \\
Beneath hearth (A97) & OSL-010412: $1860-1440 \mathrm{BC}$ (soil) \\
\hline
\end{tabular}

Fig. 7. OSL-dated soil samples taken from above and beneath a radiocarbon-dated hearth (A97).

The OSL samples suggest that the infill of the field wall was put in place prior to the start of the Christian calendar and then again during medieval times. This means that the fields adjacent to the field wall were in use during the early Iron Age, as well as in medieval times.

\section{MODERATING THE DATA}

The typological dating of the field wall did not yield any certain results; it seems as likely to have been erected in the early Iron Age as during early modern times. Radiocarbon dates from inside the field wall supported a late dating, but this can be explained by known facts about historical land-use. The study of land-survey maps and medieval records indicates that the field wall may be older than the late Viking Age or the early Middle Ages.

The extension of the field wall in the landscape tells us that the wall was most probably prehistoric. It was built slightly after two quadratic stone monuments. Such monuments are usually dated to the Roman Iron Age or the Migration period. OSL samples from within the stone wall indicate that it was built and put into use in the early Iron Age. This is slightly contradicted by radiocarbon dates from two hearths on which the field wall was superimposed and which were used in the Roman Iron Age.

The conditions under which a sample is taken are not the easiest. Samples have to be taken in darkness with only red lights to guide the sampling and it may be that some OSL samples (samples nos. 2 and 3) were by accident taken just underneath the field wall. This may explain the great age of these two samples. If samples nos. 2 and 3 are considered to represent a phase prior to the building of the field wall, the OSL results are more in line with the other methods of dating, especially the two dated hearths underneath the field wall.

Whatever the truth about the sampling may be the field wall seems to have been built in the later part of the Roman Iron Age or during the Migration period. However, a Migration-period date is maybe slightly too young if the radiocarbon dates of some 35 hearths and post-holes primarily from the settlements are taken into consideration. These dates tend to cluster in the early Iron Age and only a few dates are as late as from the Migration period. However, there is always the possibility that the settlements and activities creating hearths were situated elsewhere during the Migration period. The site might have been in agricultural use later. The vegetation historical data tell us that regression occurred sometime in 
the late Iron Age ( $7^{\text {th }}-9^{\text {th }}$ centuries AD). The Migration period, however, appears to have been expansive, according to data collected in bogs and lakes. It must also be remembered that the infilling of crevices within a wall must take place sometime after the construction. Thus it remains possible that the wall was built sometime before the dates provided by infilling sediments.

It is clear that the dating of agrarian remains is tricky. It is easy to get trapped by dates from other sites, even if the dates are irrelevant (or incorrect) for the site under examination. As we have shown in this study, radiocarbon dates (as well as OSL dates) must be handled carefully if they are not to be misleading. If sites with dates that are incorrectly interpreted are used as arguments for the dating of another site, false conclusions will be repeated.

\section{PROPOSED INTERPRETATION}

The Öggestorp site shows traces of intensive activity and settlement primarily in the Pre-Roman and Roman Iron Ages. At least two farms belonging to this period have been identified. Arable fields seem to have been cleared and many grave monuments were built. The main structure on the site, the field wall, was not the first feature structuring the landscape. It was most probably built in the later part of the Roman Iron Age or in the Migration period. It is thus a relatively late element to be added to an already existing, agrarian landscape. The vegetation historical data, however, tell us that the site was not abandoned during the Migration period; on the contrary, the Migration period seems to have been an expansive phase with intensive cultivation and grazing. The field wall and its context indicate that infields and outlying lands were separated in a systematic way during the Migration period. This re-organisation of the agrarian landscape is correlated with an intensification of the agrarian production, shown in the pollen diagrams. For northern Småland, previous research has suggested that extensive cultivation with long-term fallow, supposed to be typical of the cairn fields (Sw. röjningsröseområde), was not succeeded by intensive cultivation in permanent fields (Sw, ensäde) before the Viking Age or the Middle Ages (Lagerås 1996:10; 2002:57; Vestbö-Franzén 1997:209; 1998:16). However, the conclusion from Öggestorp is more in agreement with the development of the agrarian landscape in Östergötland, though a little delayed (Widgren 1983; Ericsson 2000).

The impetus to re-organise the agrarian landscape and to build the field wall most probably came from the plains of Östergötland where walls (but of a different kind) hedged infields already in the Roman Iron Age (ibid). It is hard not to relate this intensification of agrarian production with growth in population (Boserup 1965). However, in recent years, such explanations have not been in great demand. Instead, post-processual archaeology has searched for symbolic meanings, transcending practical functions. Some attempts have been made regarding the interpretation of field walls (e.g. Andrén 1989; Burström 1994; Cassel 1998). In our opinion, such interpretations are often superficial and idealistic and can in no way supersede economic and social explanations. However, boundaries are 
artefacts: in nature, there are just differences of degree. Once built, a field wall is a striking construction, separating different kinds of land. A manifest boundary is suitable for metaphorical thinking (Fig. 8). In traditional societies, it is often dangerous or even forbidden to transcend social categories. Such people are often stigmatised. In medieval Europe, witches were creatures who literally rode on fences. The Swedish word for "witch" (häxa) comes from the Old High German Hagazussa. The first part of this word is formed on the word hage, originally meaning "enclosure" (Sw. inhägnad) or "fence" (Sw. gärdesgård). In Havamal (verse 155), we read about demonic women riding on fences or túnriður as they are called in the poem. Tun is also an old word for fence. According to the oldest code of medieval law in Sweden (Äldre Västgötalagen) it was an insult to say to a woman that she had been riding on a fence. This folklore about boundaries was made up of once concrete elements in the agrarian landscape.

The area of Öggestorp and Rommelsjö seems to have witnessed regression in the later part of the Iron Age. The Öggestorp site contains no archaeological traces from this period. In the plains of Östergötland (Widgren 1983; Ericsson 2000) and fertile parts of Småland such as Möre (Ericsson 2001b), a structural change of the rural landscape is discernible during the later part of the Migration period and the early Vendel period (AD 550-800). Approximately the same time, a devastation of settlement occurred in the uplands and some areas were forested and abandoned. These changes were part of the same process. In the High Middle Ages, independent data show us that there was a further period of activity in Öggestorp. In one way or another, the land around the field wall was once again used for agriculture, which resulted in charcoal and a new phase of sediment accumulation within the wall.

\section{CONCLUDING REMARK}

We argue that no single method can be used for dating agricultural remains or, more specifically, field walls. The only approach to a convincing date for the field wall in Öggestorp is to combine different methods and to use them as the foundation of an argumentation for a plausible date of the feature and its culturalhistorical context. More specifically, this means that archaeologists must be as

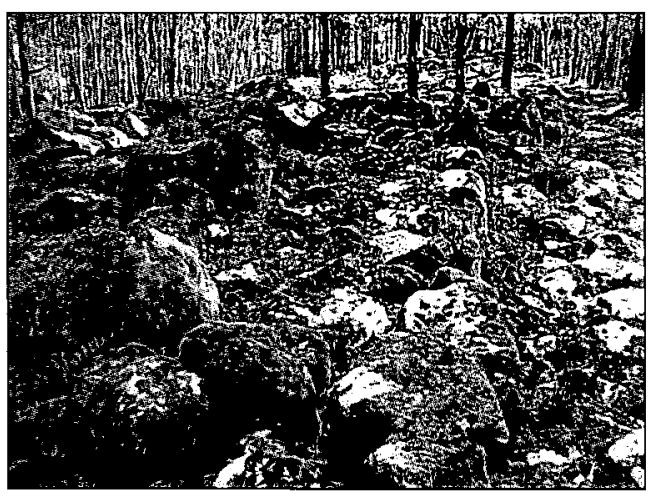
open-minded as possible concerning dating methods. We must not simply rely on radiocarbon dates as singlemindedly and heavily as Swedish archaeologists so often tend to do.

Fig. 8. A three sided grave in Landseryd parish, Östergötland. This grave from the early Iron Age show similar construction details as the field wall discussed in the article. Photograph by Alf Ericsson, National Heritage Board. 


\section{ACKNOWLEDGEMENTS AND COMMENTS}

The archaeological excavations in Öggestorp were carried out in order to clear the way for a new road. The Swedish National Road Administration (SNRA) defrayed the cost of the excavations. We wish to thank Professor Mats Widgren and Dr. Per Lagerais for valuable comments on an earlier draft of this paper. The shareware OxCal 3.5 was used for calibrating ${ }^{14} \mathrm{C}$ data. Relevant ${ }^{14} \mathrm{C}$ data have been presented within parenthesis. The ${ }^{14} \mathrm{C}$ data are presented uncalibrated, together with the laboratory numbers.

\section{English revised by Neil Tomkinson.}

\section{REFERENCES}

Andrén, A. 1989. Dörrar till förgångna myter. En tolkning av de gotländska bildstenarna. In: Andrén, A. (Ed). Medeltidens födelse. Symposier på Krapperups borg 1. Pp. 287-319. Lund.

Baran, J. 2002. Interpreting the distribution of absorbed dose in an incompletely zeroed natural luminescent dosimetre. Department of Radioisotopes. Institute of Physics, Silesian University of Technology. Poland. (http://www.jkpglm.se/arkeologi/PDF/thesis.pdf)

Baran, J, Murray, A.S. \& Häggström, L. 2003. Estimating the age of stone structures using OSL: the potential of entrapped sediment. Quaternary Science Reviews 22 (2003). Pp. 1265-1271.

Baudou, E. 1973. Arkeologiska undersökningar på Halleby: Del I. Studies in North-European Archaeology 3. Stockholm.

Björkman, L. 2003a. Pollenanalytisk slutundersökning av tre torvmarkslokaler frän Öggestorps och Rogberga socknar inför ombyggnaden av Riksväg 31, delen Öggestorp-Akarp, Jönköpings kommun. LUNDQUA Uppdrag 45. Kvartärgeologiska avdelningen. Lunds universitet. Lund.

2003b. Pollenanalytisk undersökning av jordprover från gravar, röjningsrösen och markprofiler vid trafikplatsen Öggestorp $i$ Öggestorp socken inför ombyggnaden av Riksväg 31, delen Öggestorp Akarp, Jönköpings kommun. LUNDQUA Uppdrag 44. Kvartärgeologiska avdelningen. Lunds universitet. Lund.

Boserup, E. 1965. The Conditions of Agricultural Growth. The Economics of Agrarian Change under Population Pressure. London.

Burström, M. 1994. Platsens arkeologi. Stensträngar i tankevärld och vardagspraktik. In: Jensen, R. (Ed). Odlingslandskap och fångstmark. (En vänbok till Klas-Göran Selinge). Pp. 67-74. Stockholm.

Bøtter-Jensen, L. 2000. Development of Optically Stimulated Luminescence Techniques using Natural Minerals and Ceramics, and their Application to Retrospective Dosimetry. Risø National Laboratory, Roskilde. (http://www.risoe.dk/rispubl/NUK/nukpdf/ris-r-1211.pdf)

Cassel, K. 1998. Från grav till gård. Romersk järnålder på Gotland. Stockholm Studies in Archaeology 16. Stockholm.

DS. Diplomatarium Suecanum (the old succession).

Dovring, F. 1947. Attungen och marklandet. Studier över agrara förhållanden i medeltidens Sverige. Lund. - 1953. Agrarhistorien. Stockholm.

Edlund, N.D. 1926. Våra östgötska fäders värn mot fienden. Norrköpings tidningar 20/2 - 13/3 1926.

Engman, F \& Nordström, M. 2001. Trehundratio röjningsrösen och en grav - markutnyttjande under tusen år i Vetlandatrakten. Tidskrift-arkeologi i sydöstra Sverige nr 1. Pp. 9-24.

Ericsson, A. 1999. Fossilt odlingslandskap i Närke. In: A. Ericsson (Ed). Odligslandskap och uppdragsarkeologi. Artiklar från Nätverket för arkeologisk agrarhistoria. Riksantikvarieämbetet, Avdelningen för arkeologiska undersökningar, Skrifter nr 29. Pp. 10-28. Linköping.

- 2000. Odlingslandskapets arkeologi. In: Vetenskaplig verksamhetsplan för UV Öst. Riksantikvarieämbetet. Pp. 18-32. Linköping.

- 200 la. Järnålderns hägnadssamhälle. In: Hemmet - trakten - världen. Meddelanden från Östergötlands 
länsmuseum. Arsbok 2001. Pp. 83-106. Linköping.

-2001 b. Möre mellan järnålder och medeltid: omvandlingen av ett agrarlandskap. In. Magnusson, M. (Ed).

Möre: historien om ett Småland. Pp. 367-414. Kalmar.

Franzén, G. 1994. Stensträngen som arkeologiskt objekt. Seminar paper. Department of archaeology, Stockholm University. (http://franzark.com/)

Golabiewski Lannby, M. 2002. Den inmurade skatten i Öggestorps kyrka. In: Berglund, B. \& Börjesson, K. (Eds). Markens minnen. Landskap och odlingshistoria på småländska höglandet under 6000 år. Pp. 111-112. Stockolm.

Göransson, S. 1985. De regelbundna strukturerna i Östsveriges bebyggelsegeografi. I: H. Aldskogius et al. (Eds). Kulturgeografiska perspektiv. (Geografiska regionstudier 15. Kulturgeografiska institutionen, Uppsala universitet). Pp. 65-82. Uppsala.

Gren, L. In press. Hackerör i Njudungs västra härad: regional analys och detaljstudier i Norra Sandsjö.

Grün, R. 2001. Trapped charge dating (ESR, TL, OSL). In: Brothwell, D.R. \& Pollard, A.M. (Eds). Handbook of Archaeological Sciences. Pp. 47-62. Chichester.

Häggström, L. 2003. Öggestorps åkrar. Åldersbestämning av agrarhistoriska lämningar, metodutveckling och förutsättningar in om uppdragsarkeologin. In Situ 2002. Pp. 37-47.

Jansson, K. 2002. Arkeologi längs väg. In: Berglund, B. \& Börjesson, K. (Eds). Markens minnen. Landskap och odlingshistoria på småländska höglandet under 6000 år. Pp. 58-93. Stockolm.

Lagerås, P. 1996. Long-term history of land-use and vegetation at Femtingagölen - a small lake in the Småland uplands, southern Sweden. In Vegetation and land-use in the Smáland Uplands, southern Sweden, during the last 6000 years. Lundqua Thesis 36 . Lund.

- 2002. Landskapsutveckling och markanvändning. In: Berglund, B. \& Börjesson, K. (Eds). Markens minnen. Landskap och odlingshistoria på småländska höglandet under 6000 år. Pp. 32-57. Stockolm.

Larsson, L. O. 1981. Småländsk bebyggelsehistoria 1. Från vikingatid till Vasatid. Acta Wexionensia. Serie 1. History \& Geography 1:1. Växjö.

Mascher, C. 1993. Förhistoriska markindelningar och röjningsröseområden $i$ Västsveriges skogsbygder. Kulturgeografiskt seminarium 2/93. Kulturgeografiska institutionen, Stockholms universitet. Stockholm.

Murray, A.S. \& Olley, J.M. 1999. Determining sedimentation Rates using Luminescence Dating. In Bruns \& Haas (Eds). On the Determination of Sedimentation Rates. GeoResearch Forum vol 5 (1999). Pp. 121-144.

Nicklasson, P. 1997. Suärdet ljuger inte. Vapenfynd frän äldre järnålder på Sveriges fastland. Acta Archaeologica Lundensia. Series prima in $4^{\circ} \mathrm{N}^{\circ} 22$. Lund.

Nordén, A. 1930. Stensträngarnas ålder och uppgift. Fornvännen 1930. Pp. 136-151.

- 1943. Östergötlands järnålder, del 2. Stockholm.

Ranheden, H. 1999. Arkeobotaniska analyser av fossila odlingslager: något om möjlighter och problem. In: A. Ericsson (ed). Odligslandskap och uppdragsarkeologi. Artiklar från Nätverket för arkeologisk agrarhistoria. Riksantikvarieämbetet, Avdelningen för arkeologiska undersökningar, Skrifter nr 29. Pp. 74-83. Linköping.

Regnell, Mats. 2003. Växtmakrofossilanalyser av jordprover från Riksväg 31, Öggestorp, Småland. Göteborgs Universitet, Arkeologiskt Naturvetenskapligt Laboratorium rapport 2003:21, Göteborg.

Vestbö-Franzén, Aa. 1997. Aspekter på odling. Jordbruk och odlingslandskap i Jönköpings län under förhistorisk tid och medeltid. Det nära förflutna - om arkeologi i Jönköpings län. Småländska kulturbilder 1997. Pp. 194-211. Jönköping.

- 1998. Jordbruksutveckling och bebyggelsestruktur i Vireda socken. In: Viredabygden 2. Vireda hembygdsförening. Pp. 16-37. Jönköping.

- 2002. Odlingslandskapets organisation i Öggestorp, Rommelsjö och Axlarp. In: Berglund, B. \& Börjesson,

K. (Eds). Markens minnen. Landskap och odlingshistoria på småländska höglandet under 6000 år. Pp. 95-126. Stockolm.

Widgren, M. 1983. Settlement and Farming Systems in Early Iron Age. A Study of Fossil Agrarian Landscapes in Östergötland, Sweden. Stockholm Studies in Human Geography 3. Stockholm

- 1990. Strip fields in an Iron-Age context: a case study from Västergötland, Sweden. Landscape history 12. Pp. $5-24$. 